\title{
Aplikasi Penggunaan Daun Ubi Jalar Dan Ampas Tahu Sebagai Pakan Tambahan Untuk Meningkatkan Performa Domba Lokal Di Desa Gudang Kecamatan Tanjungsari
}

\section{Application Of The Use Of Sweet Potato Leaves And Tofu Waste Cake As An Additional Feeds To Improve Local Sheep Performance In Gudang Village Tanjungsari District}

\author{
Iman Hernaman ${ }^{1, a}$, Atun Budiman ${ }^{1}$, M. Fatah Wiyatna ${ }^{1}$, dan Johar Arifin ${ }^{1}$ \\ ${ }^{1}$ Fakultas Peternakan Universitas Padjadjaran \\ Jl. Raya Bandung-Sumedang Km 21 Jatinangor Sumedang45363 \\ aemail: iman.hernaman@unpad.ac.id
}

\begin{abstract}
Abstrak
Limbah pertanian lokal berupa daun ubi jalar dan ampas tahu yang berada di Desa Gudang berpotensi sebagai bahan pakan penguat untuk meningkatkan performa domba. Oleh karena itu untuk penerapannya perlu dilakukan penyuluhan dan demosntrasi plot agar dapat diadopsi oleh peternak. Kegiatan ini dlakukan secara bertahap, yaitu 1) observasi lapangan dan menghimpun kepustakaan, 2) penyuluhan, 3) demonstrasi plot. Penyuluhan telah dilakukan di SD Cikupa Desa Gudang Kecamatan Tanjungsari yang dihadiri oleh 24 orang peserta, lalu dilanjutkan dengan demonstrasi plot. Hasil menunjukkan bahwa terjadi peningkatnya pengetahuan peternak dan masyarakat tentang potensi bahan pakan terurama bahan pakan penguat berupa daun ubi jalar dan ampas tahu. Uji coba di lapangan telah menunjukan bahwa domba yang diberi daun ubi jalar dan ampas tahu terjadi peningkatan bobot badan harian sebesar 55,8 g/hari. Kesimpulan, penyuluhan dapat meningkatkan pengetahuan peserta tentang bahan pakan dan performa domba meningkat dengan pemberian daun ubi jalar dan ampas tahu sebagai bahan pakan penguat.
\end{abstract}

Kata kunci : ampas tahu, domba, daun ubi jalar, demonstrasi plot, dan penyuluhan

\begin{abstract}
Local agricultural waste in the form of sweet potato leaves and tofu waste cake in Gudang Village has the potential as feed ingredients to improve sheep performance. Therefore, to implement it, counseling and demonstration of plots must be carried out so that farmers can adopt them. This activity is carried out in stages, namely 1) field observations and collecting literature, 2) counseling, 3) plot demonstrations. Counseling was conducted at SDN Cikupa, Gudang Village, Tanjungsari District, which was attended by 24 participants, then continued with a demonstration plot. The results showed that there was an increase in the knowledge of farmers and the community about the potential of feed ingredients, especially sweet potato leaves and tofu waste cake. Field trials have shown that sheep given sweet potato leaves and tofu waste cake had increased daily bodyweight of $55.8 \mathrm{~g} /$ day. Conclusion, counseling can increase participants' knowledge of feed ingredients and the performance of sheep increased by giving sweet potato leaves and tofu waste cake.
\end{abstract}

Keywords: tofu waste cake, sheep, sweet potato leaves, plot demonstration, and counseling 


\section{Pendahuluan}

Kecamatan Tanjungsari memiliki posisi strategis sebagai daerah pemasok berbagai kebutuhan ternak bagi masyarakat kota Bandung. Hal ini karena jarak dengan ibukota propinsi tersebut hanya berkisar 25 Km. Di samping itu, kecamatan ini lokasinya berdekatan dengan pasar hewan yang terletak di kota Kecamatan Tanjungsari. Pasar hewan tersebut merupakan satu-satunya tempat pemasaran hewan di Kabupaten Sumedang.

Keberadaan pasar hewan selain meningkatkan roda perekonomian, juga telah merangsang masyarakat di sekitar wilayah tersebut untuk memelihara berbagai aneka ternak ruminansia. Termasuk sebagian masyarakat di Desa Gudang yang terletak hanya sekitar $2 \mathrm{~km}$ dari pasar hewan tersebut. Hal ini terungkap dari data potensi desa yang menunjukkan bahwa ternak yang dipelihara cukup banyak dan beragam. Masyarakat di Desa Gudang banyak yang memelihara ternak domba dengan jumlah peternak yang memeliharanya sebanyak 152 jiwa, sedangkan jumlah domba yang dipelihara sebesar 408 ekor. Ternak ini mudah dalam pemeliharan dan penanganannya serta beranak banyak dan dalam tempo dua tahun dapat melahirkan anak-anaknya sampai 3 kali. Selebihnya ternak lain yang banyak dipelihara adalah sapi yang umumnya digunakan sebagai ternak kerja, sisanya kambing, kerbau dan kuda.

Selama ini peternak seringkali menemui banyak masalah yang dihadapinya terutama dalam meningkatkan produktivitas. Performa ternaknya. Pada banyak potensi pakan penguat ayang ada di sekitar mereka. Persoalan tersebut muncul, kemungkinan karena kurangnya pengetahuan dan bagaimana cara menyajikannya pada ternak.

Potensi bahan pakan penguat yang berada di Desa Gudang cukup melimpah, diantaranya daun ubi jalar. Daun ini selain sebagai sumber serat juga mengandung protein yang tinggi untuk memberikan pasukan sumber $\mathrm{N}$ bagi mikroba rumen maupun $\mathrm{Di}$ samping itu juga di Desa Gudang terdapat beberapa pabrik tahu yang mengahasilkan hasil samping berupa ampas tahu yang mudah dicerna dan juga sebagai sumber protein. Kombinasi ampas tahu dengan daun ubi jalar diharapkan menjadi sumber pakan penguat yang dapat meningkatkan performa domba lokal.
Pada hakekatnya potensi sumber pakan di Desa Gudang cukup melimpah, namun pengetahun peternak tentang potensi tersebut dapat ditingkatkan melalui penyuluhan dan demonstrasi plot. Penyuluhan memiliki peranan dalam peningkatan proses adopsi teknologi peternakan (Abdullah, 2008), sedangkan demonstrasi plot yang diharapkan peternak dapat melakukannya, karena sangat efektif dalam meningkatkan keteramplan dan pengetahuan petani (Hindersah, dkk., 2016). Bowling dan Barbara (2002) mengemukakan bahwa program penyuluhan dapat membentuk perubahan perilaku melalui prinsip berbagi pengetahuan, dan pengalaman dengan masyarakat. Bersama-sama masyarakat, dapat dilakukan berbagai kegiatan yang mengarah pada pembentukan perilaku masyarakat.

\section{Materi dan Metode Pelaksanaan}

Program pengabdian kepada masyarakat di Desa Gudang dilakukan melalui kursus singkat dengan metode penyuluhan yang dipadu dengan demonstrasi plot yang dilakukan di peternak dengan pola yang sesungguhnya dengan menggunakan domba peternak sebagai hewan percontohan. Adapun tahapan yang dilakukan meliputi:

(1) Persiapan

a. Observasi daerah sasaran dengan melakukan konfirmasi dengan berbagai pihak terutama peternak tentang tatacara pemberian ransum pada ternaknya serta bagaimana potensi bahan pakan yang ada di sekitar mereka, apakah sudah digunakan, apakah ada kendala dari penggunaan bahan pakan tersebut.

b. Memilih dan menghimpun kepustakaan yang relevan untuk memecahkan persoalan yang terjadi.

(2) Penyuluhan

Kegiatan penyuluhan dilakukan secara kelompok dengan cara tatap muka bersama peserta, membagi brosur, ceramah, dilanjutkan dengan diskusi.

(3) Demonstrasi Plot

Uji coba lapangan di peternak dilakukan dengan maksud untuk membuktikan bahwa pemanfaatan limbah pertanian dan pangan dapat meningkatkan performa domba. Uji coba lapangan dilakukan di peternak domba dengan menggunakan 4 
ekor domba lokal selama 8 minggu. ditambahkan pakan penguat berupa daun ubi jalar dan ampas tahu. Daun ubi jalar diperoleh dari kebun ubi yang ada disekitar mereka, sedangkan ampas tahu diperoleh dari pabrik tahu yang terletak di Desa Gudang.

\section{Hasil dan Pembahasan}

Pada penyuluhan dan praktek yang diselenggarakan di SDN Cikupa dihadiri oleh 24 peserta yang terdiri dari kepala desa, tokoh masyarakat, dan peternak. Cukup banyaknya peserta yang hadir sangat membantu dalam penyampaian pesan dalam penyuluhan ini. Diskusi yang terjadi saat penyuluhan berjalan cukup baik. Banyak pertanyaan yang dilontarkan dan umumnya tertuju pada materi yang disampaikan. Di samping itu, beberapa peternak/petani menceritakan pengalamannya sehingga menambah ilmu bagi peserta yang lain dan juga bagi tim pengabdian pada masyarakat LPM UNPAD. Mereka juga menginginkan perlu dilakukan kegiatan serupa namun tidak hanya satu bidang peternakan namun juga bidang lain seperti pertanian, karena selama ini mereka belum tersentuh dengan kegiatan penyuluhan dari dinas pertanian.

Antusias peternak dalam mengikuti program pengabdian pada masayarakat menunjukan keinginan terjadinya perubahan sikap. Sikap dapat ditumbuhkan dan dikembangkan melalui proses belajar yang tidak terlepas dari proses komunikasi dimana terjadi proses tranfer pengetahuan dan nilai (Suharyat, 2017). Adopsi inovasi merupakan suatu proses mental atau perubahan perilaku baik yang berupa pengetahuan (cognitive), sikap (affective), maupun keterampilan (psychomotor) pada diri seseorang sejak ia mengenal inovasi sampai memutuskan untuk mengadopsinya setelah menerima inovasi (Rogers dan Shoemaker, 1971).

Hasil yang dicapai pada saat uji coba ke ternak domba berbasis rumput lapangan dengan penggunaan limbah pertanian berupa daun ubi jalar secara ad libitum dan limbah industri pangan yaitu ampas tahu sebanyak 2 ember kapasitas $3 \mathrm{~kg}$ untuk 4 ekor domba sebagai pakan tambahan menunjukkan hasil yang cukup baik dengan rata-rata bobot badan sebesar 55,8 g/hari (Tabel 1).
Domba tersebut diberi rumput lapang dan Pertambahan bobot badan ini masih di atas rata-rata pertambahan bobot badan yang bila hanya diberi rumput saja berkisar 25-50 g per hari. Pemberian limbah tersebut menurut keterangan peternak menyebabkan nafsu makan meningkat. Hal ini menunjukkan pakan lokal sangat baik sebagai bahan pakan ternak domba dan tampaknya pemeliharaan domba dengan ransum limbah pertanian dan industri pangan tidak memberikan dampak yang negatif malahan menguntungkan dengan adanya kenaikan bobot badan harian selama uji coba dalam kurun waktu 8 minggu.

Ampas tahu biasanya digunakan sebagai konsentrat tunggal dan hanya dikombinasikan dengan rumput sebagai sumber hijauan. Ampas tahu mudah dicerna sebagai sumber N (Sutardi, dkk. 1983) dikombinasikan dengan hijauan sebagai sumber energi (TDN) akan menghasilkan kombinasi yang tepat untuk kebutuhan ternak domba. Beberapa laporan penelitian telah menunjukan bahwa ampas tahu yang diberikan ad libitum akan meningkatkan pertambahan bobot badan domba (Pulungan, et. al. 1985).

Sementara itu,daun ubi jalar dapat dijadikan bahan pakan sumber protein karena mengandung protein kasar hingga mencapai 25-29\% (Hong, 2003). Penggunaan daun ubi jalar sebanyak 20-30\% dalam ransum berbasis rumput lapang menghasilkan pertambahan bobot badan sebanyak 87 - 109 g/hari (Wargiono dan Sudaryanto 2008). Di lain pihak Kebede et al. (2008) menyatakan bahwa pemberian daun ubijalar dapat menggantikan konsentrat pada ransum kambing sebanyak $50 \%$.

\section{Kesimpulan}

Telah terlaksana kegiatan penyuluhan sebanyak 2 kali dan demonstrasi plot yang dihadiri oleh kepala desa, tokoh masyarakat, dan peternak. Peternak menunjukan ketertarikan dalam kegiatan ini dengan indikator banyaknya yang datang dan berperan aktiv selama kegiatan penyuluhan berlangsung. Penggunaan daun ubi jalar dan ampas tahu sebagai pakan penguat pada ransum domba berbasis rumput lapangan telah menghasilkan pertambahan bobot badan sebesar 55,8 g/hari. 
Tabel 1. Hasil Uji Coba Penggunaan Daun Ubi Jalar dan Ampas Tahu sebagai Pakan Tambahan pada Domba di Peternak Selama 8 Minggu

\begin{tabular}{lcccc}
\hline Periode & \multicolumn{5}{c}{ Domba } \\
\cline { 2 - 5 } & $\mathrm{A}$ & $\mathrm{B}$ & $\mathrm{C}$ & $\mathrm{D}$ \\
\hline Sebelum (kg) & 33 & 36 & 32 & 15 \\
Sesudah (kg) & 37 & 38 & 33,5 & 20 \\
Selisih (kg) & 4 & 2 & 1,5 & 5 \\
Rataan PBB (g/hari) & 71,43 & 35,71 & 26,78 & 89,28 \\
Rataan Umum PBB (g/hari) & \multicolumn{5}{c}{55,8} \\
\end{tabular}

Keterangan : PBB $=$ Pertambahan Bobot Badan

\section{Daftar Pustaka}

Abdullah, A. 2008. Peranan penyuluhan dan kelompok tani ternak untuk meningkatkan adopsi teknologi dalam peternakan sapi potong. Prosiding Seminar Nasionat Sapi Potong - Palu, 24 November 2008. Hal. 188195.

Bowling, C. J. dan Barbara A.B. 2002. Shaping Communities through Extension Programs. Journal of Extension, June 2002 Volume 40 Number 3.

Hindersah, R., Hermawan, W., Mutiarawati, T., Kuswaryan, S., Kalay, A.M., Talahaturuson, A. dan Risamasu, R. 2016. Penggunaan demonstrasi plot untuk mengubah metode aplikasi pupuk organik pada lahan pertanian sayuran di Kota Ambon. Dharmakarya: Jurnal Aplikasi Ipteks untuk Masyarakat.5 (1) : 9-15.

Hong T.T.T. 2003. Evaluation of sweet potato leaves as a protein source for growing pigs in Central Vietnam. MSc Thesis Departmen of Animal Nutrition and Management, SLU, Uppsala.

Kebede, T., T. Lemma, E. Tadesse And M. Guru. 2008. Effect of level of substitution of sweet potato (Ipomea batatas L) vines for concentrate on body weight gain and carcass characteristics of browsing Arsi-Bale goats. J. Cell. Anim. Bio. 2(2): 3642.

Pulungan, H., J.E. van Eys, dan M. Rangkuti. 1984. Penggunaan ampas tahu sebagai makanan tambahan pada domba lepas sapih yang memperoleh rumput lapangan. Ilmu dan Peternakan. 1(7):331-335.
Roger, E.M. and F.F. Shoemaker. 1971. Communication of Innovation: A Cross Cultural Approach. The Free Press. New York.

Suharyat, Y. 2017. Hubungan antara sikap, minat dan perilaku manusia. ejournal-unisma.net/ ojs/index.php/region/article/downloa $\mathrm{d} / 22 / 20$. Diakses 2 Mei November 2019.

Sutardi, T., N.A. Sigit, T. Toharmat. 1983. Standarisasi Mutu Protein Bahan Makanan Ruminansia Berdasarkan Parameter Metabolismenya oleh Mikroba Rumen. Fapet IPB Bekerjasama dengan Direktur Jenderal Pendidikan Tinggi, Departemen Pendidikan dan Kebudayaan, Jakarta.

Wargiono, J. dan B. Sudaryanto. 2000. Cassava leaves and forage crops for ruminant feed in the establishment of sustainable cassava farming system in Indonesia. Proc. National Workshop-Seminar on Sustainable Livestock Production on Local Feed Resources, held in Ho Chi Minh City, Vietnam. Jan 18 - 20, 2000. pp. $496-503$. 